Original paper

\title{
Learning from Voices in the Field: The Role of Disaster Education in Reducing Vulnerability in Urban and Rural Afghanistan
}

\author{
Marina Hamidzada ${ }^{1}$ and Ana Maria $\mathrm{Cruz}^{2}$
}

Received: 16/11/2018 / Accepted: 22/11/2019 / Published online: 23/04/2020

\begin{abstract}
Recent studies have shown that the frequency of natural disasters in the world has been increasing. This trend has had serious consequences for people throughout the world. Many studies have also found that in natural disasters, there is a general tendency that women are at higher risk than men. Several factors increasing the vulnerability of women in disasters have been elucidated. Among these, a lack of disaster education has been identified as a primary factor. This study is a follow up to a previous study carried out by the present authors in January 2017 in rural and urban communities in Afghanistan. In September 2017, a nonprofit organization conducted a series of disaster education and risk assessment programs in many parts of Afghanistan, which included communities in both rural and urban areas. The aim of the present study is to understand the effect that the education program had on the two case study communities in Afghanistan. The data was collected by conducting focus group discussions and interviews, and analyzed using grounded theory. We found a positive effect of the disaster education program in the short-term by raising awareness, increasing knowledge and promoting actions. The study confirmed previous findings on disaster education's role in reducing the vulnerability of women. It also revealed that women can play a very important role at the time of a disaster, and they can be good agents for dissemination of the gained knowledge and information to the whole community. Recommendations include the need for follow-up studies in the near future in order to understand the medium and long-term effects.
\end{abstract}

Key words: Women's vulnerability, Afghanistan, Disaster education, Rural and urban communities

\footnotetext{
${ }^{1}$ Management International System (MSI), AMELA Project, Kabul , Afghanistan marina.hamidzada@gmail.com.

${ }^{2}$ Disaster Prevention Research Institute, Kyoto University, Kyoto, Japan.
} 


\section{INTRODUCTION}

The number of natural disasters is growing in the world, inflicting serious consequences on people, property and the environment (Cvetkovic \& Ivanov, 2014). It is known that in general, the effects suffered by people in natural disasters are not distributed equally, with more vulnerable populations suffering greater levels of harm. In this paper, we investigate one aspect of this general trend by considering the effect of gender as a determining factor in the rates of harm incurred by people in natural disasters.

There is strong evidence that in natural disasters, women are more vulnerable to injury and death than men (Enarson, 2009). However, it has also been found that the factors making women more vulnerable in disasters differ among societies (Aryabandu, 2009; Valdes,2009; Saad, 2009).

In Afghanistan also, it has been found that women and young girls are affected disproportionately in natural disasters (Oxfam, 2009). Hamidzada et al. (2019) found that access to disaster education is a key factor affecting the vulnerability of Afghan women in agreement with previous studies in other parts of the world (Takauchi and Shaw,2009; Parkinson,2014; Gokhali,2009; Meagan,2012 ). Plan International (2013) found that women are often prevented from receiving the same level of disaster education as men, and this increases their vulnerability. That study also pointed out that exclusion of women from disaster management processes results in a much higher probability of death in natural disasters for women and children, with a rate as much as 14 times higher than for men in developing countries. The fact that men and women do not have the same educational opportunities was highlighted in a 2003 United Nations document that stated: "men and women in a society do not have the same opportunities for education neither in 'normal' times, nor when a disaster strikes" (UNISDR, 2003. Cited in UNDP, 2010).

Nuemayer \& Plumper (2008) identified factors related to culture, availability of resources and opportunities, and access to education affecting the rates of victimization in disasters. In a 2009 study, the United Nations Office for Disaster Risk Reduction (UNISDR, 2009) highlights the importance of disaster education for empowering women in disasters. The Hyogo Framework for Action (HFA) 2005-2015, priority for action 3, emphasizes the role of "knowledge and education" and highlights that disaster education and awareness raising are important components of disaster risk reduction. The Sendai Framework for Disaster Risk Reduction 2015-2030, emphasizes raising awareness and understanding disaster risk for reducing and preventing the risks, as a first priority for action.

However, providing a disaster education program in which women and men can participate, in some countries is a real challenge, such is the case of Afghanistan. Hamidzada et al. (2019) found that a lack of trained female staff, security and economic issues, as well as cultural and traditional practices represent challenges for the government to provide disaster education to women. 
The above studies underline the importance of inclusion of women in disaster education. Disaster education is emphasized as it is key in helping communities to be better prepared for disasters. The aim of this study is to understand the effect of a disaster education program on vulnerability factors by comparing the result of focus group discussions in rural and urban areas in Afghanistan before and after the implementation of the program. In the next sections we discuss the background of our study (section 2), and research approach (section 3). In section 4 we present the methodology of our study and in section 5 we present the discussion and results. Section 6 presents the conclusions of the study.

\section{Vulnerability of women in disasters}

Vulnerability is the degree to which people are at risk, this degree is not equal for all people (Susman and Wisner, 1983). Wisner et al. (2004) state that "Vulnerability refers to people's situation and ability to manage, tolerate and recover from the impact of a natural hazard." People around the world are vulnerable in disasters differently, but those who were vulnerable in pre-disasters, will be more vulnerable in disaster situations (Fordham, 1998). The literature shows that people who are poor and living in disaster prone areas are usually more vulnerable than others who live in safe places (Militie, 1999). This is true in both developing countries and developed countries (Bolin, 1982; 1986 cited in Enarson and Morrow 1998). Among all vulnerable groups in disaster situations, women have been found more vulnerable than men in disasters (Enarson and Morrow, 1998; Ikeda, 1996; Ishiq, 2011; Aryabandu, 2005).

The factors that make women more vulnerable in disasters vary in different societies. Aryabandu (2005) found that $60 \%$ of poor people in the world are women. The author pointed out that this poverty is the result of marginalization. Some studies highlighted that ignoring women in decision making processes is a major factor of women's vulnerability in disasters in developed and developing countries. Ikeda, 2016 argues that other factors such as age, social connections, economic development level, wealth level, health condition are the main factors of women's vulnerability in disasters. However, many studies highlighted that care giving responsibility makes women more vulnerable in disaster situations as well (Enarson \& Morrow, 1998; Ariyabandu, 2009). Denton (2012) found that due to unequal opportunity and access to resources, in developing countries $70 \%$ of women in developing countries are living under the poverty line. This situation marginalizes them from all decision making processes, especially those related to environment and climate change (UNWOMEN, 2009).

Nelson et al (2010) argued that gender relations are not integrated in the climate change development policies as a result of gender blindness of policy makers(Nelson et al, 2010: 51). Neslon stated that in developing countries women are at high risk because of cultural norms in pre-disaster time (cited in Saleem, 2013). Women's care taking responsibilities of the whole household during disasters make them more vulnerable to natural disasters than men (Enarson, 2004). 


\section{ROLE OF DISASTER EDUCATION IN DISASTER RISK REDUCTION (DRR)}

Disaster education efforts were strengthened in many nations since 1990, the International Decade of Natural Disaster Reduction (IDNDR). The positive role of disaster education in many studies has been highlighted as a tool to reduce disaster risk (Shaw et al, 2011). This has also been highlighted by UNISDR, which presents disaster education as one of the milestones for the Implementation of the Hyogo Framework for Disaster Risk Reduction (UNISDR, 2006).

In several studies, disaster education has been recognized as an important factor to help reduce disaster vulnerability. Shaw and Takeuchi (2009) noted the importance of disaster education for women, particularly in the disaster preparedness phase. Considering the role of women as good communicators in communities and families, their participation in community meetings regarding disaster education is an absolute requirement for preparedness. Nimpuno (2007) (as cited by Takauchi et al, 2011) suggests that women's level of knowledge and ability can be enhanced by participating in disaster education and preparedness. Thus, women can play a positive role to reduce the risk of disasters particularly in the areas of emergency health and sanitation as a part of disaster preparedness and risk reduction education. The author argues that women, being good communicators to their families, can effectively mobilize the participation of the whole community. Furthermore, Takeuchi et al. (2011) pointed out that instead of seeing women as a vulnerable category, they should be known for their positive roles in facilitating disaster education, preparedness and response during emergencies. The study added that women can be good agents for dissemination of the gained knowledge and information to the whole community (Takeuchi et al, 2011)

The influence of disaster education may differ between urban and rural communities (Takeuchi et al. 2011). The authors argued that disaster education in rural communities is typically transmitted from one generation to the next and that the key elements that influence disaster education are awareness of the local environment, and traditional and indigenous knowledge. Takeuchi et al. also explained that urban communities' living conditions are different from rural communities, thus education can less easily be transferred. The study pointed out that due to hectic schedules, urban people's social networks are weak, so the disaster education learning process is disconnected.

Our present study evaluated the role of a disaster education program on disaster vulnerability in a rural community and an urban community in Afghanistan. The education program comprised several activities including disaster education sessions, the development of Hazard, Vulnerability, Capacity and Risk Assessments (HVCRA), and the mapping of hazards by both women and men in each community. The disaster education program included an introduction to disaster risk reduction (DRR) concepts (e.g., hazard, risk, disaster, vulnerability and capacity), the disaster risk management process (preparedness, mitigation, prevention, response, reconstruction) and early warning systems. 
With the NGO's guidance, participants prepared plans for community disaster management. These plans reflected the needs, concerns and issues affecting all of these groups. The education program lasted one week (5 days) and participants attended the program all day. Women and men attended the program separately. They also established men and women disaster risk management committees. In each community 4 committees were established: rescue, search, health, and early warning committees.

Both communities selected for the study, due to their geographical location, are subject to many kinds of natural hazards such as earthquake, flash floods, river flood, mass movement and drought. Among all mentioned natural hazards, flood hazards represent the biggest concern for both communities which have frequently caused loss of life and property. For example, in the urban community at least two flood events occur each year. Recently, a flood channel overflowed when it was blocked due to unplanned construction, affecting the whole village. In the rural community both flash flooding and river flooding occurs frequently. The frequent floods disrupt the community's normal life, usually causing damage to agriculture fields and loss of many agriculture products. Although flood hazards have been identified as the primary hazard for both communities, the disaster education program focused on all kinds of natural hazards.

Through the use of women-only and men-only focus group (FG) discussions in both the rural and urban communities before and after conducting the disaster education program, this study investigates the role of the education program on women's and men's disaster vulnerability. Furthermore, the study assesses the level of knowledge gained and the changes in behavior and attitude of men and women in each community.

\subsection{The use of Focus Groups (FGs) in disaster studies}

Focus groups have been used in disaster studies, particularly in feminist studies. Focus groups were first used by social scientists in the 1920s. In the 1980s, this method was used by market researchers and then by other professionals to do research on issues dealing with health, social sciences and others.

Focus groups have been found to be a valuable method for collecting data in women studies (Griffin and Madriz, 2003; willkson,1999; Krueger and Casey, 2000). By conducting FGs, it is possible to listen to many ideas and voices of participants instead of one single voice, so it allows researchers to understand the opinions and ideas of the group (Willkson, 1999). The method was particularly useful in Afghanistan, where literacy rates are low, and where cultural and traditional practices limit the possibility of approaching community members, especially women, through other methods. Hamidzada et al. (2019) found that data collection through the gathering of women in a FGs was effective, and encouraged participants to talk and express their ideas. In the present study, we conducted FGs with rural and urban men and women separately. 


\subsection{Grounded Theory}

Grounded Theory (GT) was first proposed by Galser and Strauss (1965), and has gradually been recognized as an effective method for developing theory from data. By applying Grounded Theory, a researcher can obtain theoretical understanding through a systematic analysis of data (Charmez 2003). The first step in the GT process consists of coding and categorizing the data (Jones \& Alony 2011) the; second step involves the construction of theory.

GT has been used for analyzing FG discussion results, especially in feminist studies (Evans 2013). Wuest (1995) noted that a strength of this method is that it can present a collective of all women's ideas, so all women's voices can be heard. The author also highlighted that "grounded theory" is consistent with postmodern feminist studies in the recognition of multiple explanations of reality" (Wuest, 1995, p. 127). The importance of this method in feminist or women based studies was also highlighted by Plummer and Young (2010) who found that GT can reflect the various issues represented or discussed.

In a 2017 study in Afghanistan, GT was used to analyze FG discussion data providing valuable insights on women's vulnerability factors and the inter-relationship of factors preand post-disaster (Hamidzada et al. 2019).

\section{METHODOLOGY}

This study was based on a literature review, a series of interviews, and FG discussions in two case study areas in Afghanistan: a) Kabul, an urban area; and b) Mazar, a rural area. FGs were held before and after the administration of an education program in the two areas.

For data analysis, we apply grounded theory (GT) in an effort to identify the effect of the disaster education program on women and men in each community by analyzing the FG discussion transcripts. In the following sections we summarize the data collection efforts and the application of GT.

\subsection{Data collection through Interviews}

A total of 11 interviews were conducted in the first and second round of our field trip. Four interviews with an Afghan National Disaster Management Authority (ANDMA) official including the state Minister for disaster risk management, four interviews with heads of local communities in rural and urban areas, two interviews with representatives of the NGO that conducted the education programs in rural and urban areas and one interview with representatives of United Nations Development Program (UNDP) Climate Change Project. Interviews and meetings with officials of ANDMA were conducted in their Kabul office. 
Interviews with heads of communities* were held in their houses. Interviews with NGO and UNDP representatives were held in their own offices. The discussions during the interviews mainly focused on their views and awareness of the recent ANDMA activities, especially in the case study areas.

\subsection{Data collection through focus group discussions ( FGs)}

A first round of FG discussions were conducted in January 2017, before the disaster education program, and a second round in November 2017, two months after the completion of the disaster education programs in each community. In total 51 women and 79 men participated in a total of 12 FG discussions. We conduct men only and women only FGs separately. In order to understand each group's attitudes, opinions and behavior, the participants were mainly from 3 groups of actors:
A) Women who had experienced a disaster,
B) Men who had experienced a disaster.
C) Government official or employees who were dealing with such cases daily.

Participants for the focus groups were selected from previous studies by an NGO. All participants in the female and male focus groups were almost the same in both periods. In the pre-education program FGs (January 2017) the researcher was accompanied and introduced by ANDMA and NGO staff who were familiar with and trusted by the community. In the post-education program FGs, due to the high security alert in the region, all NGOs suspended their missions. Thus, they did not allow the staff to accompany the researcher. Due to the high insecurity in the area, the authors depended solely on the community leaders to accept and support our idea of holding the FGs. The head of community gathered all the participants who attended the education program, and who had participated in the first round of FGs, in addition to some new participants for each of the FG.

Twelve new male participants were introduced in the FGs that carried out after the disaster education program. They were members of disaster risk management committees. Table 1 summarizes the distribution of participants in the FG in both case study areas in both periods.

The head of ANDMA office in Kabul was present at all FGs in Kabul. In Mazar, unlike in January 2017, as was indicated above, the NGO did not allow its staff to accompany the researcher due to security issues in communities neighboring the study area. Since most of community men and women were already familiar with the researcher's activity from her earlier study in January 2017, they warmly welcomed her and actively contributed to the FG discussions. The FGs in the rural area were held in the village community hall, while the urban FGs were held in the house of the head of the community.

\footnotetext{
* In Afghanistan, a Head of Community is usually a respected, trustable member of the community who is electing by the members of the community
} 
The same set of questions prepared for each round, and the topics for discussion were given to both male and female groups in both the rural and urban communities. The data collected through the FGs were analyzed by use of Grounded Theory.

Table 1. Distribution of participants in the focus group discussions in Kabul and Mazar provinces in January and November 2017

\begin{tabular}{|c|c|c|c|c|c|c|c|c|}
\hline \multirow[t]{2}{*}{ Place / Group } & \multicolumn{2}{|c|}{$\begin{array}{l}\text { Interviews } \\
\text { ( number of } \\
\text { participants) }\end{array}$} & \multicolumn{3}{|c|}{$\begin{array}{c}\text { First round FGs } \\
\text { (Jan.2017) }\end{array}$} & \multicolumn{2}{|c|}{$\begin{array}{l}\text { Second round FGs } \\
\text { (Nov.2018) }\end{array}$} & \multirow[t]{2}{*}{ Total } \\
\hline & $\begin{array}{l}\text { Jan. } \\
2017\end{array}$ & $\begin{array}{l}\text { Nov. } \\
2017\end{array}$ & Women & Men & $\begin{array}{l}\text { DRR } \\
\text { staff }\end{array}$ & Women & Men & \\
\hline Number of FGDs & & & 3 & 3 & 2 & 2 & 2 & 12 \\
\hline $\begin{array}{l}\text { Rural area } \\
\text { Mazar, Khulm district, Sayad } \\
\text { village }\end{array}$ & 2 & 2 & 9 & 7 & 10 & 12 & 20 & 58 \\
\hline $\begin{array}{l}\text { Urban area } \\
\text { Kabul, district } 13\end{array}$ & 4 & 4 & 19 & 19 & 6 & 12 & 18 & 72 \\
\hline Total participants by gender & 6 men & 6 men & 26 & 26 & $\begin{array}{c}\text { Male } \\
15 \\
\text { Female: } \\
1\end{array}$ & 24 & 38 & $\begin{array}{c}51 \\
\text { female } \\
79 \\
\text { male } \\
\end{array}$ \\
\hline
\end{tabular}

\subsection{Grounded Theory: Coding and categorizing}

Full transcripts of all FGDs were prepared based on the field notes. Codes were selected by the researchers from the data on the basis of multiple repeated themes and issues that were highlighted by the FG participants. Each of the FG transcripts from the discussions were reviewed and coded individually. More than 500 codes were identified. Following review of the coding of all FGs, it was found that many codes were very similar and could readily be incorporated into a single category. Table 2 shows the coding process for the "Preparedness category" in rural and urban areas. Different categories were found to dominate for men and women, with many categories for women revealing the importance of disaster education for protecting women from hazards and disasters.

By comparing the FG discussion materials between the first and second round of FGs, the new responses clearly revealed the change in the level of understanding concerning disaster management. Table 3 and 4 show differences of responses before and after conducting the disaster education program in rural and urban communities. The effect that the disaster education program had on their knowledge and behavior became evident. 
Table 2. Examples of codes which fall under gaining knowledge and preparedness information from different focus groups in rural and urban communities

\begin{tabular}{|c|c|c|c|c|}
\hline $\begin{array}{c}\text { Discussion } \\
\text { point }\end{array}$ & $\begin{array}{c}\text { Women FG in } \\
\text { rural } \\
\text { community }\end{array}$ & $\begin{array}{c}\text { Women FG in } \\
\text { urban } \\
\text { community }\end{array}$ & $\begin{array}{c}\text { Men FG in } \\
\text { rural } \\
\text { community }\end{array}$ & $\begin{array}{c}\text { Men FG in } \\
\text { urban } \\
\text { community }\end{array}$ \\
\hline $\begin{array}{c}\text { The benefits } \\
\text { of disaster } \\
\text { education } \\
\text { program }\end{array}$ & $\begin{array}{c}\text { We learned } \\
\text { how to use } \\
\text { emergency kits }\end{array}$ & $\begin{array}{c}\text { We learned to } \\
\text { protect our } \\
\text { houses from } \\
\text { flood by using } \\
\text { sand bags }\end{array}$ & $\begin{array}{c}\text { We learned that } \\
\text { lack of safe } \\
\text { drinking water } \\
\text { caused many } \\
\text { problems }\end{array}$ & $\begin{array}{c}\text { We learned how } \\
\text { to cleaning } \\
\text { ditches and flood } \\
\text { channels which } \\
\text { helps to decrease } \\
\text { flooding }\end{array}$ \\
\hline
\end{tabular}

Table 3. Comparison of disaster preparedness before and after the disaster education program was conducted in the urban area

\begin{tabular}{|c|c|c|c|c|}
\hline $\begin{array}{c}\text { Discussion } \\
\text { point }\end{array}$ & $\begin{array}{l}\text { Women } \\
\text { before } \\
\text { disaster } \\
\text { education } \\
\text { program } \\
\text { (Jan. 2017) }\end{array}$ & $\begin{array}{c}\text { Woman after } \\
\text { disaster } \\
\text { education } \\
\text { program } \\
\text { (Nov. 2017) }\end{array}$ & $\begin{array}{l}\text { Men before } \\
\text { disaster } \\
\text { education } \\
\text { program } \\
\text { (Jan. 2017) }\end{array}$ & $\begin{array}{l}\text { Men after } \\
\text { disaster } \\
\text { education } \\
\text { program } \\
\text { (Nov. 2017) }\end{array}$ \\
\hline $\begin{array}{l}\text { Action taken } \\
\text { in a case of } \\
\text { flood }\end{array}$ & $\begin{array}{l}\text { They didn't } \\
\text { know flood } \\
\text { arrival until it } \\
\text { arrived at their } \\
\text { door due to } \\
\text { lack of } \\
\text { warning }\end{array}$ & $\begin{array}{l}\text { Now they have } \\
\text { warning system, } \\
\text { using phones and } \\
\text { know how to } \\
\text { protect their } \\
\text { house with sand } \\
\text { bags }\end{array}$ & $\begin{array}{c}\text { They rescued } \\
\text { neighbors } \\
\text { during the flood }\end{array}$ & $\begin{array}{l}\text { Now they can } \\
\text { announce early } \\
\text { warning for all } \\
\text { community and } \\
\text { evacuate }\end{array}$ \\
\hline $\begin{array}{l}\text { Priority } \\
\text { disaster } \\
\text { reduction } \\
\text { actions }\end{array}$ & $\begin{array}{l}\text { They didn't } \\
\text { know how and } \\
\text { where to } \\
\text { evacuate at the } \\
\text { time of a } \\
\text { disaster }\end{array}$ & $\begin{array}{l}\text { Now they know } \\
\text { safe places for } \\
\text { evacuation and } \\
\text { to call each other } \\
\text { by mobile } \\
\text { phones in order } \\
\text { to warn them of } \\
\text { possible flooding }\end{array}$ & $\begin{array}{c}\text { They wanted to } \\
\text { have proper and } \\
\text { nice gutters }\end{array}$ & $\begin{array}{l}\text { They learned how } \\
\text { to clean the } \\
\text { ditches and } \\
\text { drainage canals to } \\
\text { avoid urban } \\
\text { flooding }\end{array}$ \\
\hline
\end{tabular}


Table 4. Examples of the range of responses to the same question by different FGs before and after the disaster education program in the rural community

\begin{tabular}{|c|c|c|c|c|}
\hline $\begin{array}{c}\text { Discussion } \\
\text { point }\end{array}$ & $\begin{array}{c}\text { Women } \\
\text { before } \\
\text { disaster } \\
\text { education } \\
\text { program } \\
\text { (Jan. 2017) }\end{array}$ & $\begin{array}{l}\text { Woman after } \\
\text { disaster } \\
\text { education } \\
\text { program } \\
\text { (Nov. 2017) }\end{array}$ & $\begin{array}{l}\text { Men before } \\
\text { disaster } \\
\text { education } \\
\text { program } \\
\text { (Jan. 2017) }\end{array}$ & $\begin{array}{l}\text { Men after } \\
\text { disaster } \\
\text { education } \\
\text { program } \\
\text { (Nov. 2017) }\end{array}$ \\
\hline $\begin{array}{l}\text { Action taken } \\
\text { in the case of } \\
\text { flooding }\end{array}$ & $\begin{array}{l}\text { After carrying } \\
\text { the children, } \\
\text { will come back } \\
\text { to collect the } \\
\text { remaining } \\
\text { things }\end{array}$ & $\begin{array}{c}\text { Evacuate to a } \\
\text { safe place with } \\
\text { together with } \\
\text { children and do } \\
\text { not return }\end{array}$ & $\begin{array}{l}\text { Try to run to a } \\
\text { secure place } \\
\text { alone and if } \\
\text { possible to help } \\
\text { others }\end{array}$ & $\begin{array}{l}\text { Help others, } \\
\text { specially elders, } \\
\text { children and } \\
\text { woman }\end{array}$ \\
\hline $\begin{array}{l}\text { Priority } \\
\text { disaster } \\
\text { reduction } \\
\text { actions }\end{array}$ & $\begin{array}{l}\text { Need the safe } \\
\text { space for an } \\
\text { evacuation } \\
\text { shelter }\end{array}$ & $\begin{array}{l}\text { Now they } \\
\text { understand } \\
\text { where to go. } \\
\text { They request } \\
\text { more of these } \\
\text { kind of disaster } \\
\text { education } \\
\text { programs. }\end{array}$ & $\begin{array}{l}\text { Do not have } \\
\text { proper drainage } \\
\text { system and } \\
\text { canalization }\end{array}$ & $\begin{array}{l}\text { They can reduce } \\
\text { risk in the } \\
\text { community by } \\
\text { maintaining the } \\
\text { canals and ditches }\end{array}$ \\
\hline
\end{tabular}

\section{RESULTS AND DISCUSSION}

\subsection{Results of the Interviews}

In the interview with ANDMA and the NGO officials, they explained the recent activities of risk assessment and disaster education sessions. They elaborated that in addition to the training session, the communities were equipped with basic necessary disaster risk reduction instruments such as a siren for early warning, shovel and pick for digging the ground in order to find missing persons or things. They also donated to the communities some emergency first aid kits to use in emergency situations as well as other practical items such as warm clothes, blankets, and others. ANDMA and the NGOs officials expressed gratitude from community residents for their remarkable contribution and active participation in the risk assessment process. They highlighted the establishment of some emergency committees ${ }^{* * *}$ consisting of men and women in both communities.

\footnotetext{
** The committees aim to assist communities at the time of natural disasters. For example, they distribute firstaid kits so that victims do not have to wait for aid to arrive from the DRR agencies which often can take several days.
} 
The heads of both communities mentioned in the interviews that all donated equipment was now locked away in their communities. The rural community head informed us that some of the equipment such as the first aid kits was maintained in a room dedicated by a resident of this community as a health clinic. He advised that his community had used the shovel, pick and other equipment for digging a well. They had first taken a sample of the water to government laboratories to test its safety. This was confirmed so that now at least $40 \%$ of community residents benefit from this clean drinking water. The head of the urban community mentioned that when the NGO conducted the disaster education program, another organization had dug channels for the community to reduce blocking of drainage, and the amount of rain-water accumulating on the streets which has caused urban flooding.

\subsection{Results of the Focus Group Discussions}

Upon analyzing the FGDs many categories emerged, with analysis providing valuable information. The analysis showed that disaster education was effective for both men and women in the communities, but especially for women in both rural and urban areas. All analytic categories for each FGD were chosen according to the number of codes assigned to them. Sections 4.1 and 4.2 below elaborate on the causal factors revealed upon conducting the disaster education program in rural and urban settings that clearly demonstrate the effect of the disaster education program on participants knowledge and behavior in both communities.

\subsubsection{Results of FGs in rural area}

A total of 12 women and 20 men participated in two separate FGs. Except for very few new participants (which were exceptionally accepted), most participants in the FGs were the same as those who participated in the first round of FGs on January 2017, prior to the NGO intervention.

A substantial change was observed in participants' behavior, knowledge and ability to explain disaster issues following the disaster education program. Participants could now elaborate many details about their training and expressed their willingness to learn more. Considering the low level of literacy in rural areas, especially among rural women, their understanding of the training program, especially concerning flood hazards, was commendable. The study team selected the category of "Information" from the several information-related codes presented by the FGs.

The Women FG participants said that they learned how to help themselves and others in a proper and secure manner in a disaster. Women also learned how to use first aid kits, and other equipment. They had already attempted to practice using the first aid kits on their children. They had also learned how to search for missing people following disasters. Inclusion of women in the emergency committees, which were established by the NGO was an important strategy for reducing the level of vulnerability of women in disasters. Women learned how to tackle the current problems in their community, thus they cooperated with 
men to establish a basic health clinic. They also assigned a respected woman in the village to help women in the clinic in the absence of a professional medical staff. During the first visit to this community in January 2017, it had been found that the lack of female staff in all disaster management cycles caused many problems for women, some serious enough to result in death (Hamidzada et al. 2019). Women's group members elaborated that they had learned how women can help other women by taking some primary actions. For example, they learned how to carry out search and rescue, and to provide first aid. From the above codes, a category of "Cooperation" also emerged. Table 5 shows categories found in rural and urban men and women FGs. Figure 1 shows the rural women's group in the practical session of the disaster education program by the NGO in March 2017.

Table 5. Different categories found in rural and urban communities FGs

\begin{tabular}{|l|c|c|c|c|}
\hline \multicolumn{2}{|c|}{ Categories choose based on multiple codes } & \multicolumn{2}{c|}{ Rural } & \multicolumn{2}{c|}{ Urban } \\
\cline { 2 - 5 } & Women & Men & Women & Men \\
\hline $\begin{array}{l}\text { Information, raise awareness, gained knowledge on Disaster } \\
\text { preparedness }\end{array}$ & 0 & 0 & 0 & 0 \\
\hline Cooperation & 0 & 0 & $x$ & $x$ \\
\hline Coordination & 0 & 0 & $x$ & $x$ \\
\hline Planned economic empowerment project & & & & \\
\hline Independency and initiation & & & 0 & $x$ \\
\hline Dependency on DRR agencies & 0 & 0 & $x$ & $x$ \\
\hline
\end{tabular}

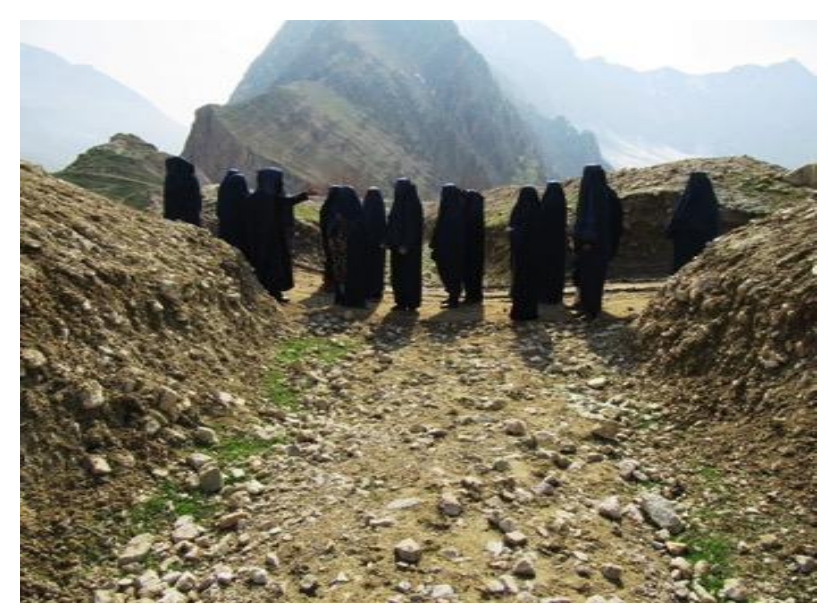

Figure 1. Rural women's group in the practical session of disaster education training (Photo credits: IOM, 2017). 
Since most of the elderly women of the community are illiterate, which prevented them from reading and using additional training guidance materials, only young schoolgirls were considered ready to conduct training for other female members of their community.

Among men FGD participants, an even larger positive change was found regarding their knowledge. Men had mapped the risk, vulnerability and capacity of village people. From this they gained enhanced information and knowledge which encouraged them to take some initiatives to solve two main issues: access to safe drinking water and access to a health clinic. They used first aid and emergency kits to establish a basic health clinic for the community. They also used the equipment such as shovels, picks, etc. for digging a well. Thus, the study team chose a category of "Collaboration" from the above codes. In addition, men had established committees, defining roles and responsibilities and a readiness to train more people. Three committees have been established so far including a First Aid Committee, an Early Warning Committee and a Search and Rescue Committee.

Generally, in rural areas it has been found that an increase in residents' level of information on disasters leads them to work together collaboratively towards community resilience to natural disasters. In both male and female FGDs, participants explored the new information and knowledge that they gained through the Disaster Education sessions. The women's group explained that they have been assigned new duties in the emergency committees, which may help them in a disaster situation. Some of these women became members of rescue and investigation committees. They learned how to prioritize who to help and rescue first in a disaster situation. For example, men FG explained that they learned how to first help children, women and elders. Figure 2 shows the effect of the disaster education program on the three categories: Gain knowledge and preparedness, Collaboration, and Cooperation.

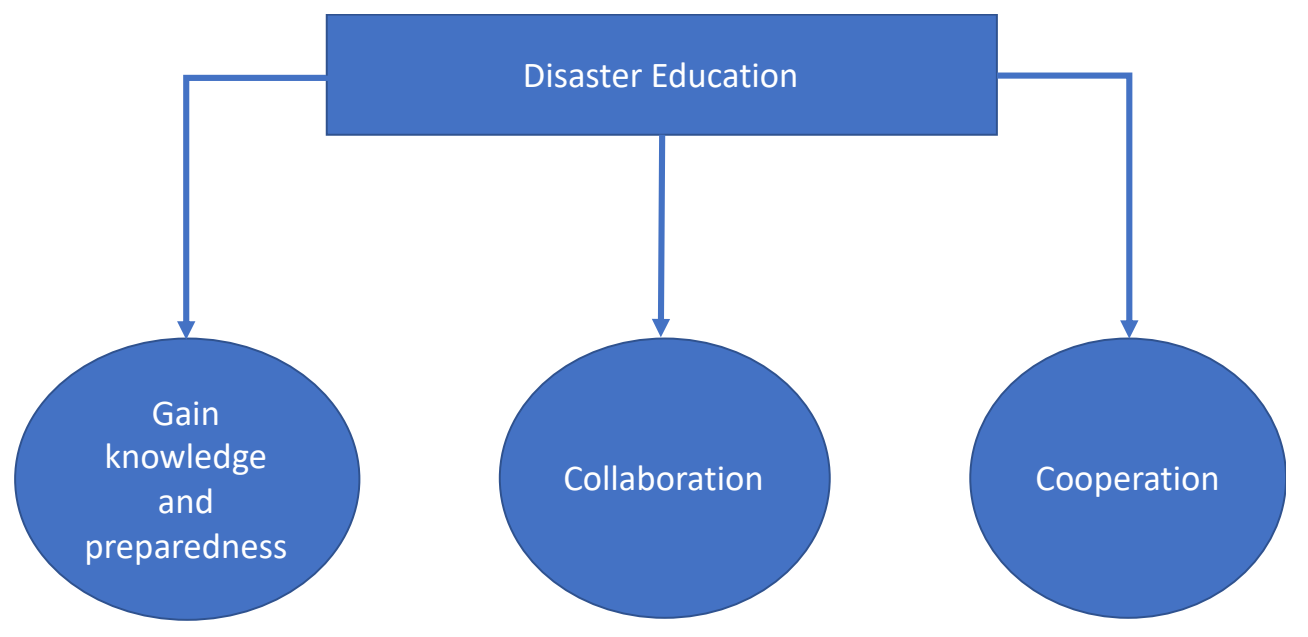

Figure 2. Effect of disaster education on the rural community behavior and knowledge 


\subsubsection{Results of FGs in the urban area}

In the urban area, 12 women and 18 men participated in the FGDs. Most participants in the FGDs were the same as those who participated in the first round of January 2017, prior to the IOM intervention. Only few new participants in the second round of FGs were introduced by the head of the community.

The men's and women's focus groups actively participated in the Disaster Education sessions and risk assessment of their community. The FG discussion revealed that the participants gained information, and knowledge. They also learned about disaster preparedness. The women group was taught how to set up small projects. During the program, they planned to establish an embroidery workshop to support their families. Thus, this new "Planned economic empowerment project" was identified as another category resulting from the disaster education program in the urban area.

Urban community men and women groups also established emergency committees such as a First Aid Committee, an Information and Early Warning Committee, and a Search and Rescue Committee. The women's group said that the training was useful, and they learned how to prepare sand bags to prevent floodwaters from entering their houses. Urban men and women said they gained more knowledge and information on urban flooding and how to map the hazard in the community. They understood that inclusion of women in management of risks is very important. Therefore, they assigned some girls and women in the committees to help community members with special needs, especially to help other women at the time of disasters.

The women and men FGs mentioned that they learned where they should go or evacuate when there is danger of flooding. After participating in the disaster education program sessions, they established an early warning system by mobile phones. They receive the early warning calls from community heads and responsible emergency committees. They can contact the members of the emergency committees when they face problems. From the above codes, the study team selected a category called "Gain knowledge and preparedness."

The men's group had not planned any new action in their community up to the time of the study team's visit. The women's group planned to establish some handicraft and embroidery courses. These courses sought to produce embroidery for market sale to empower the economic situation of poor women in the community. Thus, it can be argued that disaster education contributed to self-sufficiency and empowerment of the community. We chose "Planned economic empowerment project" category from the above mentioned codes. Figure 3 shows that the disaster education program had a direct effect on "Gain knowledge and preparedness", and "Planned economic empowerment project". 


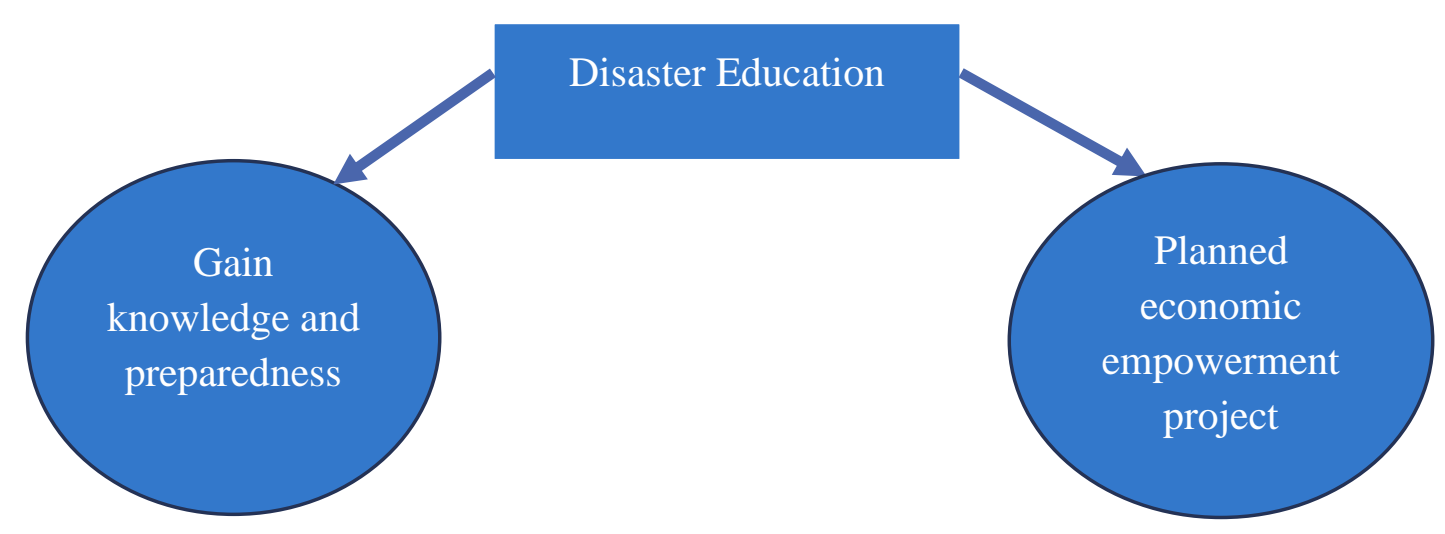

Figure 3. Effect of disaster education on the behavior and knowledge of urban community

\section{DISCUSSION}

This study investigated two communities, one in a rural and one in an urban area of Afghanistan. It explored how Disaster Education in both communities influenced people's behavior and attitudes and generally increased their awareness and information. It also explored people's motivation and action after participating in a Disaster Education program. The nature of discussion on the issues and accomplishments in implementing the Disaster Risk Reduction (DRR) plans, clearly illustrated the level of knowledge gained through trainings, and the urgency of needs in relation to the subjects being explained. For instance, the rural community needed safe drinking water, which is a human essential need. Upon receiving the equipment and training on Disaster Education, they realized the urgency of digging a well and did so.

In the urban community, there was no urgency for digging a well, so the equipment given by the NGO was not utilized immediately. The findings of the present study were compared with those of an earlier study in the same communities on their vulnerability factors in disasters (Hamidzada et al. 2019).

The findings of FGDs revealed that in rural communities the main categories or factors emerging from participation in the Disaster Education program were Collaboration, Gaining information and knowledge, and preparedness, and Cooperation. Both men's and women's attitudes and behavior regarding disaster risk reduction greatly improved following the training. Their greater knowledge and information on disasters enabled them to reduce the effect of disasters in their community. They could solve up to $50 \%$ of the essential problems for their community by digging a well to have access to safe drinking water and setting up a basic health clinic. 
In urban communities the primary categories were found to be Gaining information and knowledge and preparedness, and the proposal of a Planned Economic Empowerment project. Men and women gained greater information and knowledge about the hazards in their community. They identified a safe place for evacuation and established a basic early warning system through mobile phones. In emergency situations, they can call each other or the head of community. The women's group learned how to protect their houses by preparing some sand bags. Figure 4 highlights the outcomes of the disaster education program in rural and urban communities.

Overall, we found that the disaster education program increased the participants' knowledge and awareness about disasters and disaster preparedness in both urban and rural communities. However, in the urban community the program was less effective in empowering them to take action. For example, neither the women nor men had initiated any concrete action (at the time of the study) based on the training, while in the rural area it led to concrete actions. The following bullet points highlight some of the differences:

1- The rural community was more independent and took action and initiatives based on the training according to their knowledge and information level. The examples of digging a well to find a source of safe drinking water or establishment of a basic health clinic demonstrated this application.

2-In the rural community, men and women committee members made practical use of the equipment provided by the NGO such as tools for several purposes, and emergency response kits.

\section{Disaster education's outcomes in urban and rural areas}

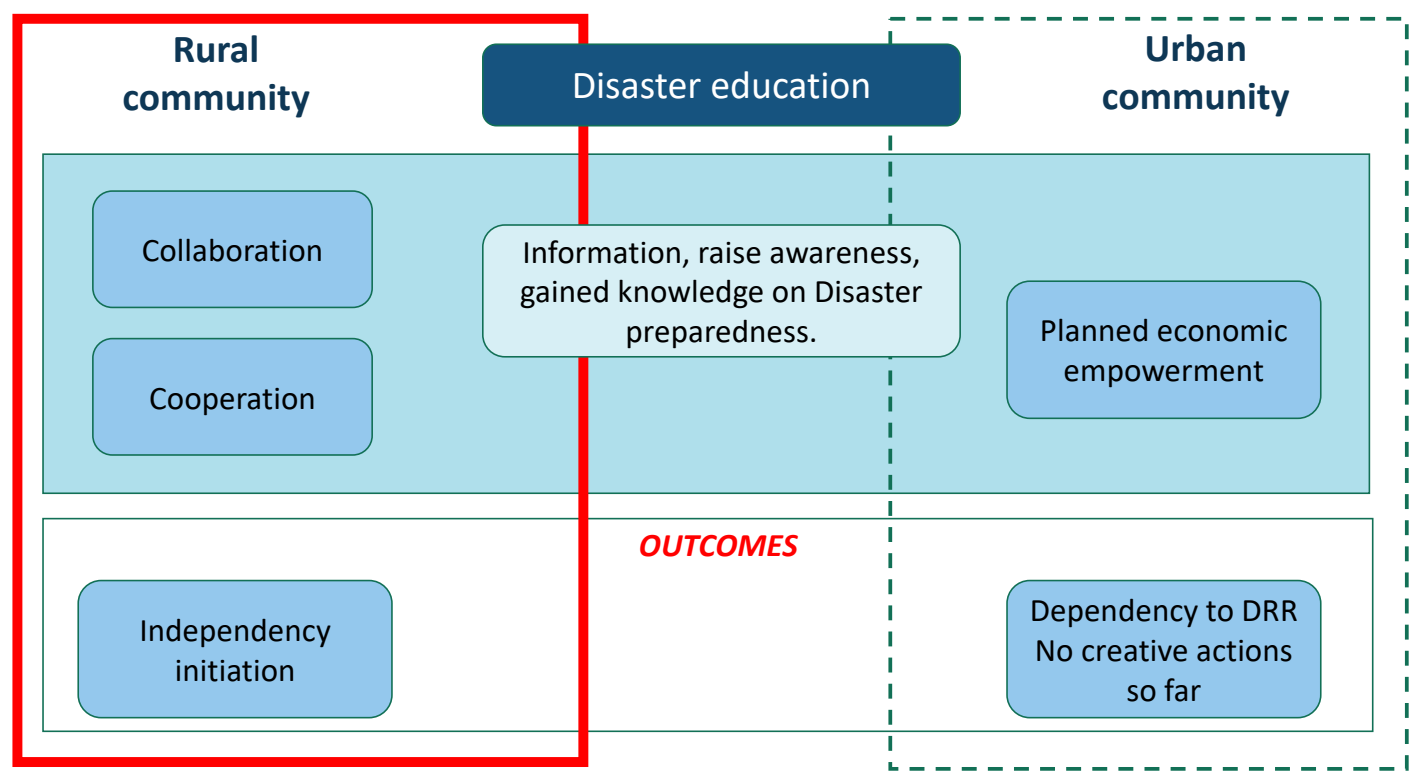

Figure 4. The disaster education program influence and outcome in rural and urban communities. 
3- Women in the rural community played a positive role despite high levels of illiteracy in rural areas. Women were able to take positive steps towards reducing the level of hazard in their community (e.g., learned how to protect homes from flood waters by using sand bags).

4- An additional and major achievement following the disaster education program was the inclusion of women in the emergency committees in both urban and rural communities. It is a first step to empowering women, especially in Afghanistan. As discussed in the introduction, women can play a crucial and positive role in helping other women in all cycles of risk management.

5- Dependency of urban community: The urban community demonstrated more dependency on the government and the DRR agencies. They learned methods to reduce hazards in their community, but thus far demonstrated no independent action. For example, urban men learned how to clean and maintain the streams and canals, but never applied this knowledge. They had no plan to start such work, often citing the lack of budget or of resources for the lack of action.

In rural communities most people are working in the fields; in urban communities most participants have jobs outside their community. These factors may substantially contribute to the level of cooperation and independent initiatives by rural communities rather than within urban communities. The effectiveness of the disaster education program appeared to have greater impact in rural areas than in the urban area we examined.

The study results were similar to previous findings on disaster education's role to reduce the vulnerability of women. For example, women learned what actions to take in the case of flooding to protect themselves and their families. In the rural community, the establishment of the health clinic for women provides the possibility for women to have access to female medical help in the case of injury or birth following disasters. The study also revealed that the influence of the disaster education program were different between urban and rural communities. We found that in rural communities, key elements that influence disaster education are awareness of their local environment, and traditional and indigenous knowledge. Similar results were observed by Takeuchi et al. (2011).

This study confirmed the findings of previous studies (Takeuchi et al. 2011; Loki 2015; UNDP 2013) that women can play a very important role at the time of a disaster, and they can be good agents for dissemination of the gained knowledge and information to the whole community. 


\section{CONCLUDING REMARKS}

The main purpose of the study was to understand the effect that a disaster education program had on the two case study communities in Afghanistan. Data for the study was collected through focus group discussions and interviews, and the data was analyzed by grounded theory. In general, the program helped to raise awareness in both rural and urban areas. However, the study showed that the influence of the disaster education program were different between urban and rural communities, with a more visible effect in the rural community. In the rural community it proved to be very effective in motivating the community to take action resulting in greater self -sufficiency and empowerment. The study also confirmed the previous finding on disaster education's role to reduce the vulnerability of women reported in the literature. Disaster education and awareness raising are important components of disaster risk reduction.

Thus, education and awareness raising sessions need to be increased and dissemination of messages on disaster risk should reach the communities. Accessibility of messages by women and diverse groups (the community level through community radios and community based gathering) is suggested.

It was confirmed by many FGs that lack of basic infrastructure increases exposure and contribute vulnerability of women and men in the communities. There is a serious need for special budget for construction of retaining walls, evacuation centers, ditches and flood channels. The budget and resources should allocate for early warning systems and recruit and train DRR female trainers and female staff too.

The voices and concerns of communities and local level actors in the national review of policies and law development, should be considered through bottom up approaches. Consideration of women's view by conducting separate sessions and inclusion of female guides for them is also a strong step to reduce the level of vulnerability.

Further research should include the analysis of the long-term effects, as well as to understand if the knowledge and information, and motivation gained and observed during this study will continue in the long run.

\section{REFERENCES}

Ariyabandu, M, M (2006). Sex, gender and gendre relations in disasters. Chapter1 in Enarson, E and Chakrabarti, P, G. Sage. Women, Gender, and disaster.

Charmaz, K. (2003). 'Grounded Theory- Objectivist and constructivist methods. In N.K. Denzin \& Y.S. Lincoln (Eds). Handbook of Qualitative Research, Second edition. London: Sage.

Enarson E (2009). Gendering Disaster Risk Reduction in Women, Gender and Disaster: Global https://www.brookings.edu/wp-content/uploads/2016/06/ND-Review-Chapter-4.pdf 
issues and initiatives, sage publication. ISBN 978-81-321-0148-2

Evans. G.L. (2013). 'A Novice Researcher's First Walk through the Maze of Grounded Theory: Rationalization for Classical Grounded Theory'. The Grounded Theory Review, 12 (1): 37-55.

Ferris, E., Petz, D., \& Stark, C. (2012). Disaster risk management: A gender-sensitive approach is a smart approach. The year of recurring disasters: A review of natural disasters. Chapter 4, 71-88. Available at: https://www.brookings.edu/wpcontent/uploads/2016/06/ND-Review-Chapter-4.pdf

Gokhali, 2008. Role of Women in Disaster Management: An Analytical Study with Reference to Indian Society. The 14th World Conerence on Earthquake Engineering October 12-17, 2008, Beijing, China

Griffin C, (1986). Qualitative methods and female experience: young women from school to the job market. In S. Wilkinson (Ed), feminist social psychology: development theory and practice (pp.173-191). Milton Keynes, England: Open University press.

Hamidzada, Marina; Ana Maria Cruz; and Muneta Yokomatsu (2019) Vulnerability Factors of Afghan Rural Women to Disasters. International Journal of Disaster Risk Science, 10 (4): 573-590. https://doi.org/10.1007/s13753-019-00227-z

Hyogo framework for action, 2005-2015. Unite Nations. Office for Disaster Risk Reduction. Accessed in: www.unisdr.org. Last accessed on 29 September 2018.

Ikeda K (2016). 63rd Session UN Committee on the EVAW Gender-related Dimensions of Disaster Risk Reduction and Climate Change. Geneva, 29 Feb 2016.

Ivanov, A., \& Cvetković, V. (2014). The role of education in natural disaster risk reduction. Horizons-international scientific journal, X, 16, 115-131.

Jones, M. \& Alony. I. (2011). 'Guideline to use of Grounded theory in doctoral studies. An example from the Australian film industry'. International Journal of Doctoral Studies, 6 (N/A): 95-114.

Krueger, R.A and Casey M.A. (2000). Focus groups: A practical guide to applied research. Third ed. Thousand Oaks, CA: Sage

Madriz, E. (2003). 'Focus groups in Feminist Research'. Chapter 10 in Denzin. N \& Lincoln Y.S. Collecting and Interpreting Qualitative Data. Sage. pp 363-384.

Neumayer E \& Plümper T (2007) The Gendered Nature of Natural Disasters: The Impact of Catastrophic Events on the Gender Gap in Life Expectancy, 1981-2002, Annals of the Association of American Geographers, 97:3, 551-566, DOI: 10.1111/j.14678306.2007.00563.x 
Oxfom (2009). The cost of war. Afghan experience of conflict1978-2009. Page 18. https://www.oxfam.org/sites/www.oxfam.org/files/afghanistan-the-cost-of-war.pdf

Parkinson, D. (2014) Women's experience of violence in the aftermath of the Black Saturday bushfires. Australia.

Petal, M. (2009). Education in disaster risk reduction. In: R. Shaw \& R. R. Krishnamurthy (Eds), disaster management: global challenges and local solutions (pp.285-320). India university press.

Plan international (2013). Because I am a Girl THE STATE OF THE WORLD'S GIRLS 2013 In Double Jeopardy: Adolescent Girls and Disasters. EU office for promoting child rights.

Plummer \& Young, 2010 Sendai framework for Disaster Risk Reduction. 2015-2030. United Nations. Office for Disaster Risk Reduction.

Rajib Shaw et al, 2011. "Role of disaster education in disaster risk reduction" in Shaw et al, 2011. Disaster education, community, environment and disaster risk reduction, volume 7. ISBN: 978-0-85724-737-7

Saad, S G (2009). Environmental management and disaster mitigation: Middle Eastern gender perspective. Chapter 7 in Enarson, E and Chakrabarti, P, G. Sage. Women, Gender, and disaster.

Saito, Y. (2014). Progress or repetition? Gender perspectives in disaster management in Japan. Disaster prevention and Management, 23(2), 98-111.

Sendai framework for Disaster Risk Reduction. 2015-2030. United Nations. Office for Disaster Risk Reduction. Page 14-16.

Shaw et al, (2004). Linking experience, education, perception and earthquake preparedness. Disaster Prevention and Management, 13(1), 39-49.

Shaw et al (2008). Education, Capacity Building and Public Awareness for Disaster Reduction in Landslides - Disaster Risk Reduction pp 499-515 by Kyoji Sassa and Paolo Canuti

Shaw R, Takeuchi Y, Gwee QR and Shiwaku K (2011). Role of education in disaster risk reduction. Chapter 1 in Shaw, R., Shiwaku, K. and Takeuchi, Y. (Ed.) Disaster Education (Community, Environment and Disaster Risk Management, Vol. 7), Emerald Group Publishing Limited, Bingley, pp. 77-94. https://doi.org/10.1108/S2040$\underline{7262(2011) 0000007010}$

Strauss A. \& Corbin J. (1998). 'Grounded theory in practice. Data management and analysis methods. In N. Denzin \& Y.S. Lincoln, and Lincoln. Collecting and Interpreting Qualitative Materials. United State of America: Sage publication. pp.259-310. 
Takeuchi, Y., Mulyasari, F. and Shaw, R. (2011), "Chapter 4 Roles of Family and Community in Disaster Education", Shaw, R., Shiwaku, K. and Takeuchi, Y. (Ed.) Disaster Education (Community, Environment and Disaster Risk Management, Vol. 7), Emerald Group Publishing Limited, Bingley, pp. 7794. https://doi.org/10.1108/S2040-7262(2011)0000007010

UNESCO, 2012. Disaster Risk Reduction: Stay Safe and be Prepared. A Reference DVD.

UNISDR, 2009. 'The disaster risk reduction process: A gender perspective'. Gender and Disasters Network. Geneva

UNSDR 2015. Women and girls are invisible force of resilience. Geneva, 2015.

Valdes, H M (2009). A gender perspective on disaster risk reduction. Chapter 2 in Enarson, E and Chakrabarti, P, G. (Eds.) Women, Gender and Disasters. Sage.

Willkson, S. (1999). Focus Groups, A feminist method. Volume: 23 issue: 2, page(s): 221224. Psychology of women quarterly. Sage journals. Issue published: June 1, 1999.

Wuest, J. (1995). 'Feminist Grounded Theory: An exploration of the congruency and tension between two traditions in knowledge discovery'. Qualitative Health Research, 5(1), 125137. 